\title{
Pelvic kidney: a challenging abnormality for surgeons
}

\section{Nerka miedniczna: anomalia stanowiąca wyzwanie dla chirurgów}

\author{
'Department of Obstetrics and Gynecology, Health Sciences University Istanbul Research and Training Hospital, Istanbul, Turkey \\ ${ }^{2}$ Department of Pathology, Health Sciences University Istanbul Research and Training Hospital, Istanbul, Turkey \\ ${ }^{3}$ Department of Radiology, Health Sciences University Istanbul Research and Training Hospital, Istanbul, Turkey \\ Correspondence: Caglar Helvacioglu, Istanbul Teaching and Research Hospital, Department of Obstetrics and Gynecology, Balıkl Kazlıçesme Yolu no:1 Zeytinburnu, Istanbul, Turkey, \\ tel.: 009050595336 48, e-mail: caglarhel@hotmail.com, 0RCID: 0000-0002-6247-2383
}

Abstract Objective: Pelvic kidney is the most common congenital renal anomaly with an incidence of 1 in 1,000 to 1 in 2,000. A pelvic kidney can be encountered at pelvic or paraaortic lymphadenectomy. Case: A 70-year-old female patient undergoing pelvic-paraaortic lymphadenectomy due to serous endometrial cancer. Due to the known right pelvic kidney, lymphadenectomy was more difficult and gentle. Conclusion: Preoperative evaluation of the pelvic kidney is important to avoid any complications during surgery. Lymphadenectomy should be more careful in patients with pelvic kidney.

Keywords: pelvic kidney, lymphadenectomy, gynecology

Streszczenie Cel: Nerka miedniczna, stwierdzana podczas limfadenektomii miedniczej lub okołoaortalnej, jest najczęstszą wrodzoną anomalią nerkową, przy czym częstość występowania tego zaburzenia szacuje się na 1/1000 do 1/2000. Opis przypadku: 70-letnia kobieta operowana metodą limfadenektomii miedniczo-okołoaortalnej z powodu surowiczego raka endometrium. $\mathrm{Z}$ uwagi na obecność prawej nerki miednicznej zabieg limfadenektomii był utrudniony. Wniosek: Ocena przedoperacyjna nerki miednicznej ma duże znaczenie, gdyż pozwala na uniknięcie powikłań śródoperacyjnych. U pacjentów z tą anomalią zabieg limfadenektomii należy przeprowadzać z zachowaniem szczególnej ostrożności.

Słowa kluczowe: nerka miedniczna, limfadenektomia, ginekologia 


\section{INTRODUCTION}

C ongenital abnormalities of the kidney and the urinary tract are rare. Renal ectopy is a common congenital anomaly of kidney and urinary tract. The incidence of renal ectopy is $1 / 1,000-5,000$ in general population $^{(1,2)}$. The etiology involves aborted ascent of the fetal kidney from its pelvic position. Pelvic kidney is located in the true pelvis and is usually a unilateral phenomenon ${ }^{(3)}$. Pelvic kidney may be associated with obstructive hydronephrosis and vesicoureteral reflux with infection or pain, but almost all cases are clinically silent. This condition comprises several anatomic anomalies, including unilateral urethral intersection of the midline, anteriorly placed renal pelvises, and atypically placed renal vessels or aberrant renal blood vessels, all of which increase the difficulty of surgery. We describe a patient with previously known pelvic kidney, undergoing surgery for serous endometrial carcinoma, and the management of the case.

\section{CASE}

A 70-year-old patient who was diagnosed with serous endometrial cancer by biopsy, was referred to our clinic. She had essential hypertension regulated by angiotensin converting enzyme blocker. There were no abnormal findings in her blood count or blood biochemical analysis. A total abdominal hysterectomy with bilateral salpingooophorectomy, pelvic-paraaortic lymphadenectomy and omentectomy was performed. Lymphadenectomy procedure was performed with some difficulties due to the right pelvic kidney (Fig. 1). First, the right kidney was mobilized from the caecum and other pelvic connections, then renal vessels and ureter of right kidney were sharply and gently dissected. After obtaining a sufficient exposure, it was easier to perform lymphadenectomy. Operation was completed without any visible residual disease or complications. Serous adenocarcinoma was diagnosed in final pathology reports. Pathology results showed that myometrial invasion was $90 \%$. A total of 46 lymph nodes were resected. The number of pelvic and paraaortic lymph nodes was 24 and 22, respectively. Micrometastases were detected in two left obturator lymph nodes and in one paraaortic lymph node at the level of inferior mesenteric artery. The patient was referred for adjuvant chemotherapy and radiotherapy with the diagnosis of stage IIIC2 serous endometrial cancer.

\section{DISCUSSION}

Pelvic kidney is a relatively rare abnormality of the urinary tract in gynecologic cancer patients who undergo surgery. In daily practice, many surgeons operate on pelvic kidney patients for different types of diseases; however, there are limited publications presenting such experience. This case is important to

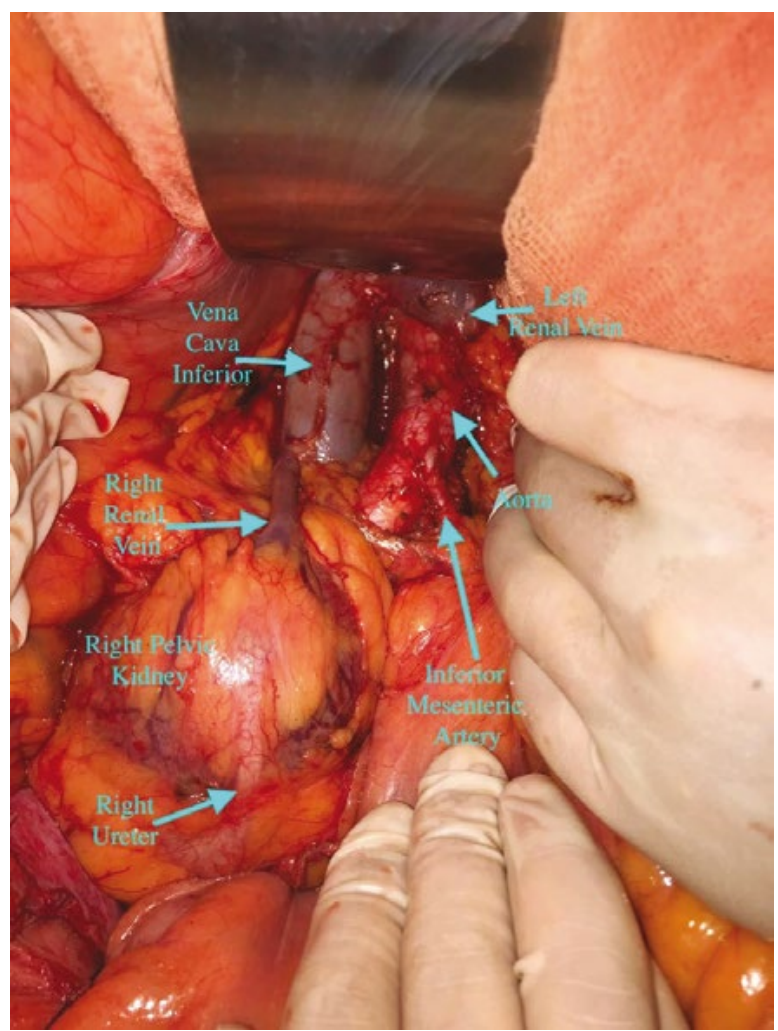

Fig. 1. Intraoperative picture of pelvic kidney and anatomical structures after lymphadenectomy

treat a pelvic kidney patient. Preoperative evaluation is very important for planning the surgical approach (Fig. 2). Adamakis et al. described two cases of pelvic kidney coexisting with bladder cancer treated with radical cystectomy and extended lymphadenectomy ${ }^{(4)}$. The authors used computed tomography (CT) before surgery. In our patient, we performed magnetic resonance imaging (MRI) to obtain information on myometrial invasion of endometrial tumor. Both CT and MRI are very helpful for a surgeon to discuss the vasculature of the kidney, anatomic placement of the ureter and renal pelvis.

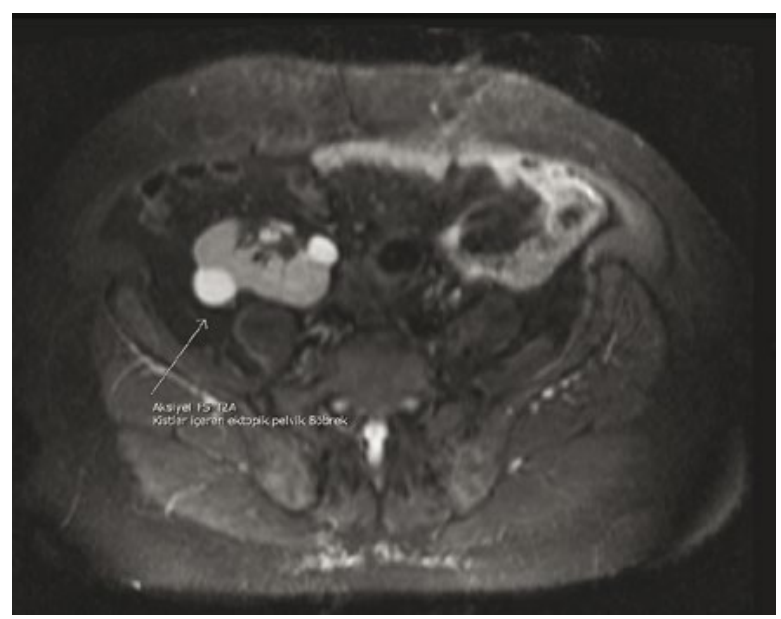

Fig. 2. Axial T2A MRI of pelvic kidney 
Three-dimensional CT and angiography are also recommended for these patients. A pelvic kidney can be diagnosed as an adnexal mass or mistaken as a bulky lymph node during preoperative imaging. Bader et al. described two cases of pelvic kidney mimicking bulky lymph nodes at pelvic lymphadenectomy in gynecologic cancer patients ${ }^{(5)}$. During the lymphadenectomy procedure, maximum care should be given to preserve kidney's vessels and ureteral anatomy. In this patient, we performed pelvic and paraaortic lymphadenectomy. As the authors described in their cases, before resecting lymph nodes we identified renal vessels and dissected the ureter near to the bladder connection ${ }^{(4,5)}$. The surgery was completed without any complications. To conclude, pelvic kidney is a challenging anatomic variation in gynecologic oncology patients who undergo surgical staging. A surgeon has to be aware of urinary tract and vessel abnormalities. Gentle dissection of renal vessels and ureter is mandatory for these patients. Surgical team should make maximum effort in order not to harm the urinary tract and renal vessels.

\section{Conflict of interest}

The authors do not report any financial or personal connections with other persons or organizations, which might negatively affect the content of this publication and/or claim authorship rights to this publication..

\section{References}

1. Sheih CP, Liu MB, Hung CS et al.: Renal abnormalities in schoolchildren. Pediatrics 1989; 84: 1086-1090.

2. Friedland GW, Deveries PA, Nino-Murica M et al.: Congenital anomalies of the kidney. In: Pollack HM (ed.): Clinical Urography. WB Saunders, Philadelphia 1990: 578-653.

3. Bauer SB: Anomalies of the upper urinary tract. In: Walsh PC, Retik $\mathrm{AB}$, Vaughan Jr ED et al. (eds.): Campbell's Urology. $8^{\text {th }}$ ed., WB Saunders, Philadelphia 2002: 1885-1924.

4. Adamakis I, Pournaras C, Katafigiotis I et al.: Radical cystectomy and lymphadenectomy to two patients with pelvic kidney: surgical pitfalls and considerations. Case Rep Med 2013; 2013: 841806.

5. Bader AA, Tamussino KF, Winter R: Ectopic (pelvic) kidney mimicking bulky lymph nodes at pelvic lymphadenectomy. Gynecol Oncol 2005; 96: 873-875. 